
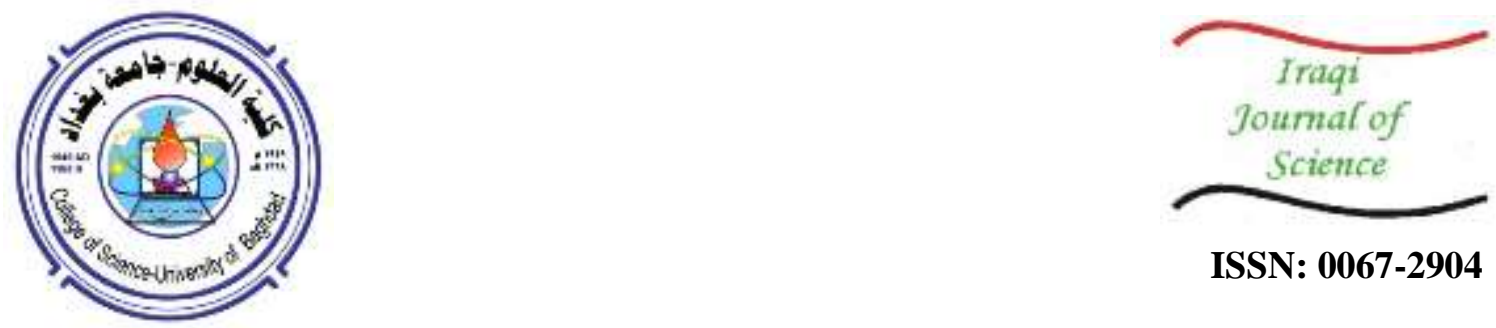

ISSN: 0067-2904

\title{
Influence of Magnetized Water and Nitrogen Bio-fertilizers on the Quantity and Quality Features of the Butternut Squash Cucurbita moschata
}

\begin{abstract}
Abbas Fadhil Ali*', Majida Hadi Mahdi Alsaady ${ }^{2}$, Hussein Ali Salim ${ }^{3}$
${ }^{1}$ College of Agriculture, University of Diyala, Diyala, Iraq

${ }^{2}$ College of Science, University of Baghdad, Baghdad, Iraq

${ }^{3}$ Directorate of Diyala Agriculture, Ministry of Agriculture, Diyala

Received: 19/5/2019 Accepted: $17 / 7 / 2019$

Abstract

The present study was carried out at Baqubah Nursery, Directorate of Agriculture, Diyala Province, Iraq, during the period of March to October 2017, to investigate the effects of magnetized water with bio and chemical fertilizers on the butternut squash. A factorial experiment with three replications was conducted and two factors were investigated; the state of water (magnetized water and nonmagnetized water) and the fertilizer type (chemical fertilizer: urea $100 \mathrm{~kg} \mathrm{~N} /$ hectare; bio-fertilizers: Azotobacterchroococcum and Azospirillumbrasilense + chemical fertilizer in 1:1 ratio).

The results revealed that the magnetized water with bio + chemical fertilizers recorded the highest rate of fruit weight that reached $786.0,807.3$ and $775.3 \mathrm{~g}$ at the first, second and third harvests, respectively. The effect of the magnetized water was significant on the rate of fruit yield/plant which reached $3745.0 \mathrm{~g}$ at the first harvest, while bio + chemical fertilizer recorded the highest rate that reached 2419.8 and $1404.3 \mathrm{~g}$ at the second and the third harvests, respectively. Magnetized water with bio + chemical fertilizers showed significant increments in total yield / plant (7822.3 g) and total yield / hectare $(31289.3 \mathrm{~kg})$. The treatment with magnetized water and bio and chemical fertilizer were significant in fruit content of total soluble solid (TSS \%) after 185 days, which reached $13.0 \%$ and $12.2 \%$, respectively, while bio + chemical fertilizer was superior in the yield of fructose sugar and fibers which reached 10.4 and $12.7 \%$, respectively.
\end{abstract}

Keywords:Butternutsquash;biofertilizer;Azotobacterchroococcum;Azospirillumbras ilense;Cucurbita moschata

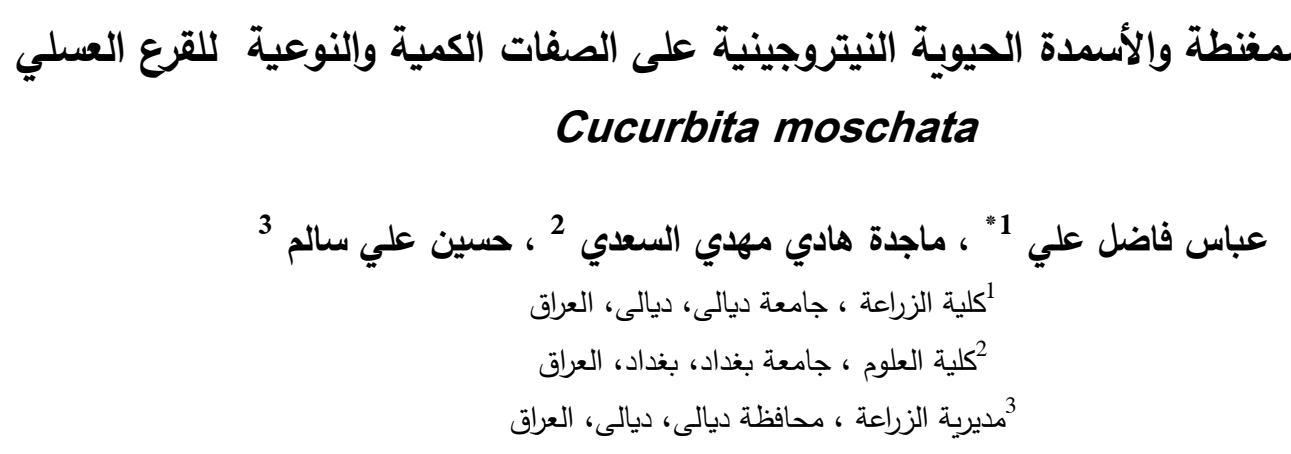

*Email: qqqqabbas@gmail.com 


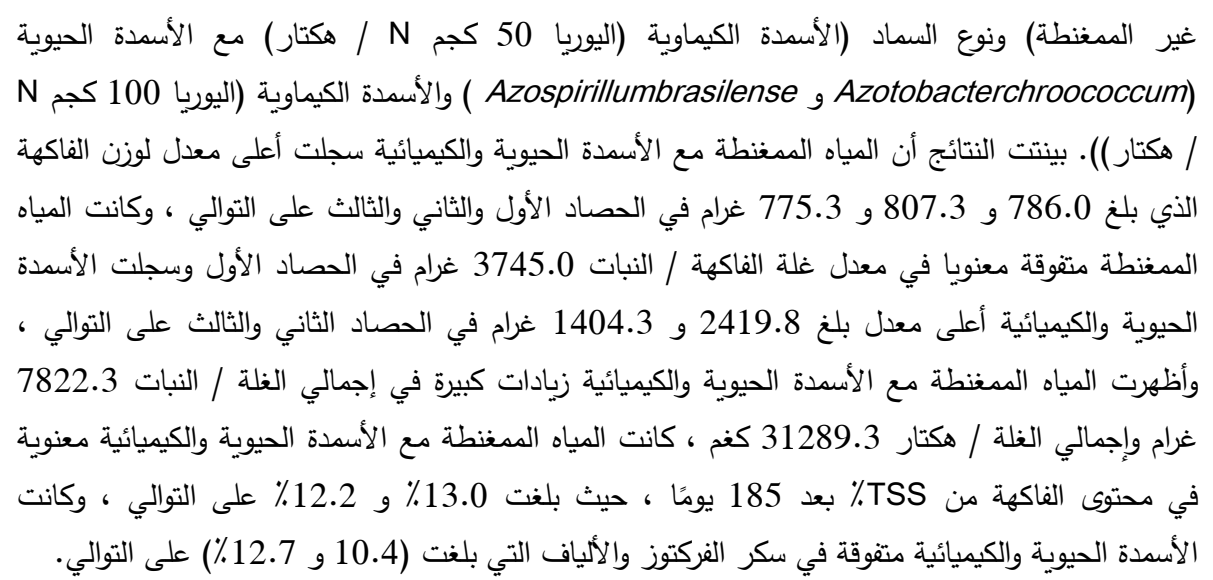

\section{Introduction}

Butternut squash Cucurbita moschata is a cultivar of pumpkin that belongs to Cucurbitaceae family and is consumed in many countries [1]. It is a staple food in the American tropics and is prepared in many ways [2]. Pumpkin fruit has nutritional and medicinal values due to total content of carotenoids, besides many minerals such as phosphorus, potassium, iron , magnesium, and selenium, as well as various vitamins such as $\mathrm{C}, \mathrm{E}, \mathrm{K}$, pyridoxine (B6), thiamine (B1) and riboflavin (B2). Pumpkin fruit also contains polysaccharides, pectin, fiber, phenolic acids and flavonoids $[3,4,5,6,7]$. Irrigation with magnetized water may minimize surface tension and change water structure, raising dissolvability of minerals and providing nutrients for plants [8]. Magnetic water has many benefits increasing the growth of shoot and root systems, rate of germination, number of fruits, development of inflorescence, and fruiting yield, as well as decreasing the solubility of salts, the amounts of irrigation water, conductivity, and $\mathrm{pH}$ [9]. A study conducted by Sadeghipour and Aghaei [10] reported that irrigation with magnetized water increased the efficiency of water usage as compared to the normal water [10]. Hozayn and colleagues showed that magnetized water helps in improving quality and yield and saving irrigation water under the sandy soil [11]. Moreover, it was reported that magnetized water increases the yield and the content of photosynthetic pigments and biochemical constituents of all tested crops [12]. The availability of nutrients in balanced and sufficient quantities is necessary for optimum plant growth[13]. Agriculture that rely on only chemical applications leads to adverse environmental consequences [14]. Excessive use of chemical fertilizers causes environmental pollution besides affecting the quality of fruit [15]. The use of bio fertilizers or organic fertilizers could be a proper option to reduce of the chemical fertilizers. Bio fertilizers are microorganisms which colonize the rhizosphere and promote plants growth through biological processes such as nitrogen fixation and solubilization of rock phosphate by converting phosphorus and nitrogen from unavailable to available forms [16]. The soil loses $25 \%$ of the applied nitrogen fertilizers due to volatilization, leaching and de-nitrification [17]. Therefore, microorganisms which fix nitrogen are playing an important role in supplementing nitrogen to the plant [18]. It was reported that the combination between biofertilizers and chemical fertilizers enhanced the grain yield of crops [19,20,21]. Azotobacter is beneficial bacteria which is free living, a non-symbiotic and aerobic nitrogen fixing [22] that results in the secretion of amino acids and vitamins and production of auxins and siderophores[23]. Azotobacter also produces indole acetic acid, thiamin, gibberellin and riboflavin [24]. Azotobacter includes six species among which Azotobacter chroococcum is the most commonly in various soils [25]. Azospirillum bacteria colonizes the roots of crops where it makes use of root excretions and fix atmospheric nitrogen. Azospirillum includes approximately 15 species and the most studied is Azospirillum brasilense. It is beneficial to plants by causing increase in the mineral uptake, improving water absorption, increasing the dry matter, enhancing plant growth, and improving the yield [26]. Therefore, the objective of this investigation is to evaluate the effects of magnetized irrigation water along with bio and chemical fertilizers on the agriculture of Butternut squash Cucurbita moschata.

\section{Materials and methods}

The field experiment was conducted at Baqubah Nursery, the Directorate of Agriculture, Diyala, Iraq, during the period of March to October 2017, to study the effect of magnetized irrigation water with bio and chemical fertilizers on Butternut squash. A factorial experiment design was carried out 
with three replicates of each treatment that involved two factors; the state of water (magnetized water and non-magnetized water) and the fertilizer type (chemical fertilizer: urea $100 \mathrm{~kg} \mathrm{~N} /$ hectare; biofertilizers: Azotobacterchroococcum and Azospirillumbrasilense + chemical fertilizer in 1:1 ratio). The data were analyzed by one way Analysis of Variance (ANOVA) [27]. The bio-fertilizer (A.chroococcum and A.brasilense) as a commercial product was obtained from the Department of Agricultural Research, Ministry of Science and Technology. Seeds were originally obtained from the Dutch seed company under the name Impectafrohandeland and planted, in 1/3/2017, in cork dishes that contain organic peat moss fertilizer under the conditions of the green house. During this period, the land was prepared for cultivation through plowing, disking and ridging. Soil samples representing depth of plowing of $0-0.15$ were taken to record the physical and chemical properties (Table-1).

Table 1-The physical and chemical properties of the soil before planting

\begin{tabular}{|c|c|c|}
\hline Measurements & Value & Unit of measurement \\
\hline Clay & 328.1 & $\mathrm{~g} / \mathrm{kg}$ soil \\
\hline Silt & 280.1 & $\mathrm{~g} / \mathrm{kg}$ soil \\
\hline Sand & 391.8 & $\mathrm{~g} / \mathrm{kg}$ soil \\
\hline Texture of soil & Mixed clay & - \\
\hline $\mathrm{CaCO} 3$ & 276.13 & $\mathrm{~g} / \mathrm{kg}$ soil \\
\hline Organic matter & 1.4 & $\%$ \\
\hline $\mathrm{N}$ & 34.89 & $\mathrm{mg} / \mathrm{kg}$ soil \\
\hline $\mathrm{P}$ & 8.13 & $\mathrm{mg} / \mathrm{kg}$ soil \\
\hline K & 347.30 & $\mathrm{mg} / \mathrm{kg}$ soil \\
\hline $\mathrm{Ca}$ & 17.45 & millmole/ liter \\
\hline $\mathrm{Mg}$ & 16.05 & millmole/ liter \\
\hline $\mathrm{Na}$ & 2.36 & millmole/ liter \\
\hline $\mathrm{HCO} 3$ & 7.9 & millmole/ liter \\
\hline $\mathrm{Cl}$ & 14.5 & millmole/ liter \\
\hline $\mathrm{So}_{4}$ & 20.85 & millmole/ liter \\
\hline $\mathrm{Co}_{3}$ & 0.0 & millmole/ liter \\
\hline Ec & 5.93 & ds Siemens $\backslash \mathrm{m}$ \\
\hline $\mathrm{PH}$ & 7.82 & - \\
\hline
\end{tabular}

The field was divided into plots (each was of $20 \mathrm{~m}$ length and $50 \mathrm{~cm}$ width). Distance between plots was $3 \mathrm{~m}$, between plants was $0.8 \mathrm{~m}$ and between replicates was $1.5 \mathrm{~m}$. Each replicate contained 5 plants. Seedlings were transferred to the field at the age of 27 days. A suspension of the biofertilizer was prepared by adding water with a ratio of 1: 1 , and then seedling roots were dipped in biofertilization suspension to facilitate adhesion of bacteria on the roots. Superphosphate fertilizers were applied at the rate of $100 \mathrm{~kg} \mathrm{P}_{2} \mathrm{O}_{5} /$ ha as recommended by the Ministry of Agriculture, with equal tillage before planting for all treatments. Nitrogen fertilizers in the form of urea fertilizer were added in three times: the first before planting, the second after the first harvest of the fruit (65 days ) and the 
third after the second harvest (95 days) at a rate of $100 \mathrm{~kg}$ nitrogen / ha. for the treatments included with chemical fertilizers and half of this amount for the treatments included with biofertilizers. Nitrogen fertilizers were added to each plant by drilling the soil close the plant. A device of water magnetizing was installed at the beginning of the drip irrigation lines with magnetic flux density of 1500 Gauss (Figure-1). Water was pumped through the drip irrigation system. The following parameters were considered to assess the effect of each treatment: fruits yield per plant, total yield per plant, total yield per hectare, rate of fruit weight per replicate, the amount of sugars and fiber in fruits, and total soluble solid (TSS). In addition, total chlorophyll was measured by Opti-sciences device (Figure-2) using 20 old leaves and 20 fresh leaves.

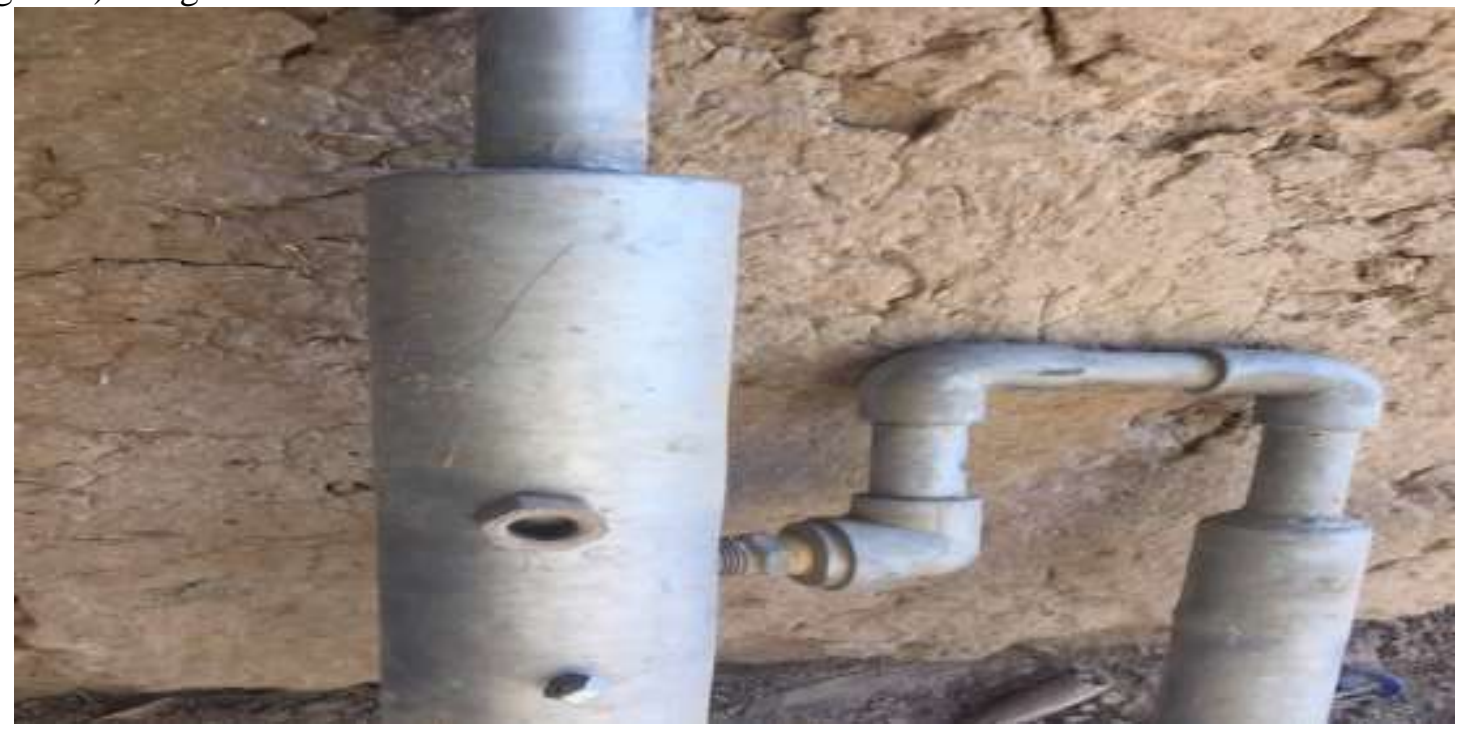

Figure 1-The water magnetizing device.

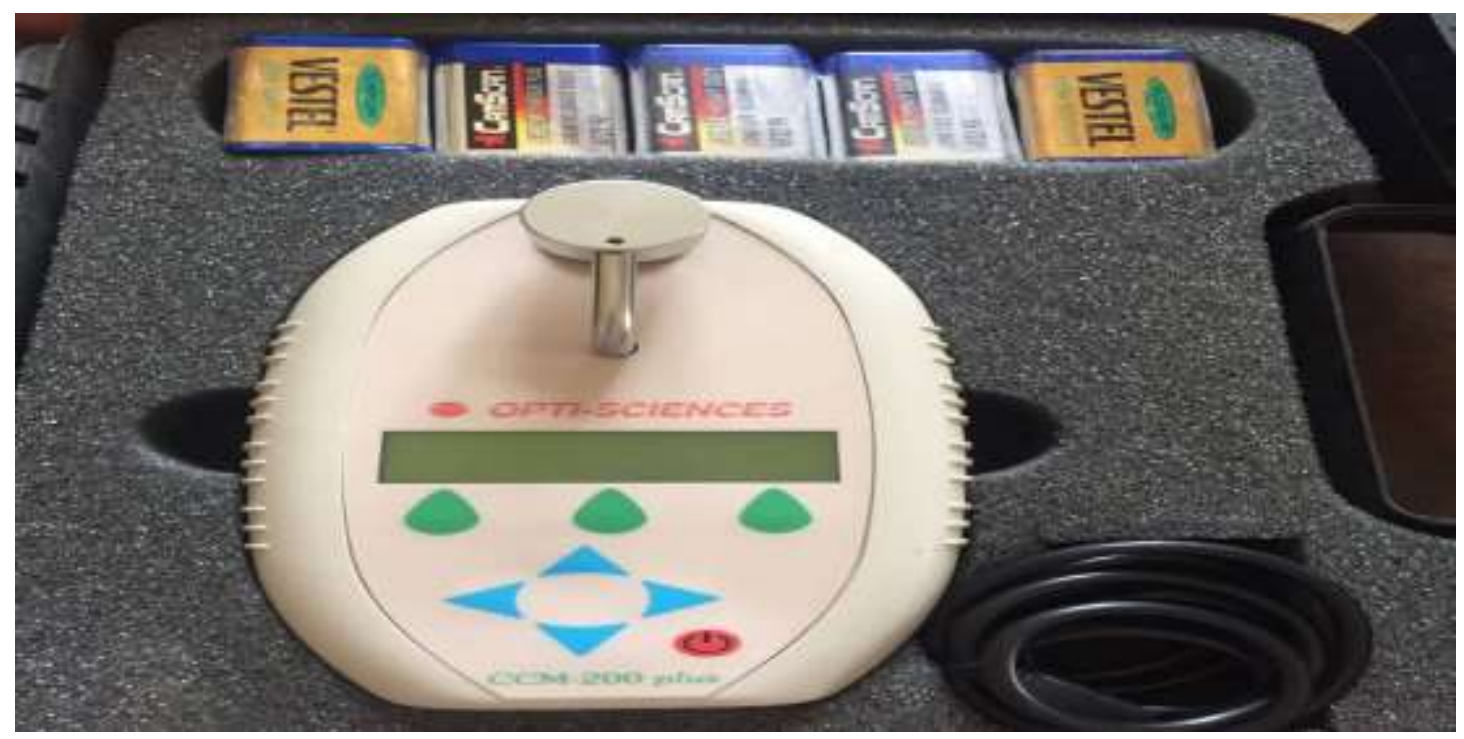

Figure 2-Chlorophyll estimation device.

\section{Results}

Effects of water state and the fertilizer type on rate of fruit weight/ replicate Analysis of variance in Table-2 showed that differences in the rate of fruit weight per replicate at the first harvest was nonsignificant between magnetized and non-magnetized water, while the bio and chemical fertilizer had the highest mean performance (764.6 g) with significant differences as compared to the chemical fertilizer $674.1 \mathrm{~g}$. The treatment of magnetized water with bio and chemical fertilizer showed the highest rate of fruit weight $(786.0 \mathrm{~g})$ during the combined treatment of the state of water and the fertilizer type.The results demonstrated that the magnetized water had a maximum effect on the rate of fruit weight at the second harvest $(776.5 \mathrm{~g})$ with significant differences from that of the non- 
magnetized water $(745.1 \mathrm{~g})$. Also, the treatment with the bio and chemical fertilizers was superior in rate of fruit weight $(803.1 \mathrm{~g})$ from that with the chemical fertilizer $(718.5 \mathrm{~g})$, while the combine between state of water and the fertilizer type was significant. The magnetized water with bio and chemical fertilizer recorded the highest rate of fruit weight $(807.3 \mathrm{~g})$. No significant differences between magnetized water and non-magnetized water and between bio andchemical fertilizer and chemical fertilizer in rate of fruit weight at the third harvest $(615.3,719.5 \mathrm{~g}$ and $719.6,615.1 \mathrm{~g}$, respectively). Treatment of non-magnetized water with bio and chemical fertilizer had the highest rate of fruit weight $(775.3 \mathrm{~g})$ during the combined treatment between state of water and the fertilizer type.

Table 2-Effect of water state and the fertilizer type on rate of fruit weight/ replicate (g) after 65, 95 and 185 days.

\begin{tabular}{|c|c|c|c|}
\hline \multicolumn{4}{|c|}{ Rate of fruits weight/replicate(g) (first harvest)after 65 days } \\
\hline \multirow{2}{*}{$\mathbf{B}$} & \multicolumn{3}{|c|}{$\mathbf{A}$} \\
\hline & Magnetized water & Non magnetized water & Rate \\
\hline Chemical fertilizer & 671.6 & 676.6 & 674.1 \\
\hline Bio and Chemical fertilizers & 786.0 & 743.3 & 764.6 \\
\hline Rate & 728.8 & 710.0 & \\
\hline CD 0.05 & \multicolumn{3}{|c|}{$\mathrm{A}=25.1, \mathrm{~B}=25.1, \mathrm{~A} \times \mathrm{B}=35.6$} \\
\hline \multicolumn{4}{|c|}{ Rate of fruits weight /replicate(g) (second harvest)after 95 days } \\
\hline & Magnetized water & Non magnetized water & Rate \\
\hline Chemical fertilizer & 745.6 & 691.3 & 718.5 \\
\hline Bio and Chemical fertilizers & 807.3 & 799.0 & 803.1 \\
\hline Rate & 776.5 & 745.1 & \\
\hline $\mathrm{CD} 0.05$ & \multicolumn{3}{|c|}{$\mathrm{A}=27.6, \mathrm{~B}=27.6, \mathrm{~A} \times \mathrm{B}=39.1$} \\
\hline \multicolumn{4}{|c|}{ Rate of fruits weight/replicate(g) (third harvest)after 185 days } \\
\hline & Magnetized water & Non magnetized water & Rate \\
\hline Chemical fertilizer & 566.6 & 663.6 & 615.1 \\
\hline Bio and Chemical fertilizers & 664.0 & 775.3 & 719.6 \\
\hline Rate & 615.3 & 719.5 & \\
\hline CD 0.05 & \multicolumn{3}{|c|}{$\mathrm{A}=54.3, \mathrm{~B}=54.3, \mathrm{~A} \times \mathrm{B}=76.8$} \\
\hline
\end{tabular}

\section{Effect of water state and the fertilizer type on rate of fruits yield/plant}

The effect of magnetized water was significant on rate of fruits yield/plant at first harvest $(3745.0 \mathrm{~g})$ compared with non-magnetized water $(2685.0 \mathrm{~g}$, Table- 3$)$. Also bio and chemical fertilizers treatment was superior to chemical fertilizer $(3568.3,2861.6 \mathrm{~g}$, respectively). Magnetized water with bio and chemical fertilizers recorded the maximum rate $4026.6 \mathrm{~g}$ with significant differences in the 
combination between the state of water and the fertilizer type. There were non-significant differences between magnetized water and non-magnetized water in rate of fruits yield/plant at second and third harvest. Bio and chemical fertilizers recorded the highest rate (2419.8 and $1404.3 \mathrm{~g}$, respectively) as compared with the chemical fertilizer (1910.0 and 658.6g, respectively). Additionally, the treatments of magnetized water with bio and chemical fertilizer , and non-magnetized water with bio and chemical fertilizer were recorded the highest at second and third harvest reached2394.6,2445.0 $\mathrm{g}$ and $1414.3,1394.3 \mathrm{~g}$ respectively.

Table 3-Effects of water state and fertilizer type on rate of fruits yield/plant (g)after 65, 95 and 185 days during culturing.

\begin{tabular}{|c|c|c|c|}
\hline \multicolumn{4}{|c|}{ Rate of fruits yield/plant (g) (first harvest)after 65 days } \\
\hline \multirow{2}{*}{ B } & \multicolumn{3}{|c|}{ A } \\
\hline & Magnetized water & Non magnetized water & Rate \\
\hline Chemical fertilizer & 3463.3 & 2260.0 & 2861.6 \\
\hline Bio and Chemical fertilizers & 4026.6 & 3110.0 & 3568.3 \\
\hline Rate & 3745.0 & 2685.0 & \\
\hline $\mathrm{CD} 0.05$ & \multicolumn{3}{|c|}{$\mathrm{A}=273.0, \mathrm{~B}=273.0, \mathrm{~A} \times \mathrm{B}=386.1$} \\
\hline \multicolumn{4}{|c|}{ Rate of fruits yield/plant (g) (second harvest)after 95 days } \\
\hline & Magnetized water & Non magnetized water & Rate \\
\hline Chemical fertilizer & 1960.3 & 1859.6 & 1910.0 \\
\hline Bio and Chemical fertilizers & 2394.6 & 2445.0 & 2419.8 \\
\hline Rate & 2177.5 & 2152.3 & \\
\hline CD 0.05 & \multicolumn{3}{|c|}{$\mathrm{A}=312.3, \mathrm{~B}=312.3, \mathrm{~A} \times \mathrm{B}=441.7$} \\
\hline \multicolumn{4}{|c|}{ Rate of fruits yield/plant (g) (third harvest)after 185 days } \\
\hline & Magnetized water & Non magnetized water & Rate \\
\hline Chemical fertilizer & 628.6 & 688.6 & 658.6 \\
\hline Bio and Chemical fertilizers & 1414.3 & 1394.3 & 1404.3 \\
\hline Rate & 1021.5 & 1041.5 & \\
\hline $\mathrm{CD} 0.05$ & \multicolumn{3}{|c|}{$\mathrm{A}=58.2, \mathrm{~B}=58.2, \mathrm{~A} \times \mathrm{B}=82.3$} \\
\hline
\end{tabular}

\section{Effect of water state and fertilizer type on total yield per plant and per hectare}

Results in Table- 4 show that the effect of magnetized water was significant in the rate of total yield / plant and total yield / hectare (6937.3 g and $27749.3 \mathrm{~kg}$, respectively) compared with nonmagnetized water (5851.5 g and $23406.0 \mathrm{~kg}$ respectively). Bio and chemical fertilizers recorded the highest rate of total yield / plant and total yield / hectare (7403.5 g and $29614.0 \mathrm{~kg}$, respectively) in comparison with chemical fertilizer (5385.3 g and $21541.3 \mathrm{~kg}$, respectively). The treatment of magnetized water with bio and chemical fertilizer showed significant increase in total yield / plant $(7822.3 \mathrm{~g})$ and total yield / hectare $(31289.3 \mathrm{~kg})$ during the combination between state the of water and the fertilizer type. 
Table 4-Effects of water state and the fertilizer type on total yield /plant (g) and total yield / hectare (kg).

\begin{tabular}{|c|c|c|c|}
\hline \multicolumn{4}{|c|}{ Total yield /plant (g) } \\
\hline \multirow{2}{*}{ B } & \multicolumn{3}{|c|}{$\mathbf{A}$} \\
\hline & Magnetized water & Non magnetized water & Rate \\
\hline Chemical fertilizer & 6052.3 & 4718.3 & 5385.3 \\
\hline Bio and Chemical fertilizers & 7822.3 & 6984.6 & 7403.5 \\
\hline Rate & 6937.3 & 5851.5 & \\
\hline CD 0.05 & \multicolumn{3}{|c|}{$\mathrm{A}=286.0, \mathrm{~B}=286.0, \mathrm{~A} \times \mathrm{B}=404.4$} \\
\hline \multicolumn{4}{|c|}{ Total yield / hectare (kg) } \\
\hline & Magnetized water & Non magnetized water & Rate \\
\hline Chemical fertilizer & 24209.3 & 18873.3 & 21541.3 \\
\hline Bio and Chemical fertilizers & 31289.3 & 27938.6 & 29614.0 \\
\hline Rate & 27749.3 & 23406.0 & \\
\hline CD 0.05 & \multicolumn{3}{|c|}{$\mathrm{A}=1144.0, \mathrm{~B}=1144.0, \mathrm{~A} \times \mathrm{B}=1617.8$} \\
\hline
\end{tabular}

Effects of water state and the fertilizer type on fruit content of total soluble solids (TSS\%)

The results of this experiment showed that the effects of magnetized water and bio and chemical fertilizers in fruit content of TSS\% were significant after 65 days, which reached $12.7 \%$ as compared with non-magnetized water and chemical fertilizer (12.3\%) ( Table- 5). Non-magnetized water with bio and chemical fertilizers recorded the highest rate in the combination between the state of water and the fertilizer type $(12.9 \%)$. However, there were no significant differences in fruit content of TSS\% after 95 days between magnetized water and non-magnetized water and between bio and chemical fertilizer and chemical fertilizer. Non-magnetized water with bio and chemical fertilizers recorded the highest rate of TSS $(13.0 \%)$. magnetized water and bio and chemical fertilizers treatment showed a significant difference $\mathrm{s}$ in fruit content of TSS \% after 185 days $(13.2 \%)$ as compared with non-magnetized water and chemical fertilizer (12.4).

Table 5-Effects of water state and the fertilizer type on fruit content from TSS\% after 65, 95 and 185 days

\begin{tabular}{|c|c|c|c|}
\hline \multicolumn{4}{|c|}{ Fruit contentfrom TSS\% (first harvest)after 65 days } \\
\hline \multirow{2}{*}{ B } & \multicolumn{3}{|c|}{ A } \\
\cline { 2 - 4 } & Magnetized water & Non magnetized water & Rate \\
\hline Chemical fertilizer & 12.2 & 12.4 & 12.3 \\
\hline Bio and Chemical fertilizers & 12.4 & 12.9 & 12.7 \\
\hline
\end{tabular}




\begin{tabular}{|c|c|c|c|}
\hline Rate & 12.3 & 12.7 & \\
\hline CD 0.05 & \multicolumn{3}{|c|}{$\mathrm{A}=0.2, \mathrm{~B}=0.2, \mathrm{~A} \times \mathrm{B}=0.3$} \\
\hline \multicolumn{4}{|c|}{ Fruit contentfrom TSS\% (second harvest)after 95 days } \\
\hline & Magnetized water & Non magnetized water & Rate \\
\hline Chemical fertilizer & 11.6 & 12.4 & 12.0 \\
\hline Bio and Chemical fertilizers & 12.9 & 13.0 & 12.9 \\
\hline Rate & 12.2 & 12.7 & \\
\hline CD 0.05 & \multicolumn{3}{|c|}{$\mathrm{A}=0.9, \mathrm{~B}=0.9, \mathrm{~A} \times \mathrm{B}=1.3$} \\
\hline \multicolumn{4}{|c|}{ Fruit contentfrom TSS\% (third harvest)after 185 days } \\
\hline & Magnetized water & Non magnetized water & Rate \\
\hline Chemical fertilizer & 12.9 & 10.3 & 11.6 \\
\hline Bio and Chemical fertilizers & 13.2 & 11.2 & 12.2 \\
\hline Rate & 13.0 & 10.8 & \\
\hline CD 0.05 & \multicolumn{3}{|c|}{$\mathrm{A}=0.4, \mathrm{~B}=0.4, \mathrm{~A} \times \mathrm{B}=0.5$} \\
\hline
\end{tabular}

Effect of water state and the fertilizer type on total chlorophyll $\mu \mathrm{mol} / \mathrm{m}^{2}$ and the content of fructose sugar\% and fibers \% in Butternut squash's fruits.

Analysis of the data revealed that the magnetized water reduced total chlorophyll $57.7 \mu \mathrm{mol} / \mathrm{m}^{2}$ as compared with non-magnetized water $83.8 \mu \mathrm{mol} / \mathrm{m}^{2}$ (Table- 6). Bio and chemical fertilizers led to increase total chlorophyll,which reached $75.4 \mu \mathrm{mol} / \mathrm{m}^{2}$, as compared to the use of chemical fertilizer $\left(66.1 \mu \mathrm{mol} / \mathrm{m}^{2}\right)$. Non-magnetized water with bio and chemical fertilizers recorded the highest rate of chlorophyll content $\left(90.0 \mu \mathrm{mol} / \mathrm{m}^{2}\right)$. No significant differences were observed between magnetized water and non-magnetized water in content of fructose sugar $\%$ and fibers $\%$ in Butternut squash's fruit, whereas bio and chemical fertilizer was superior in that trait (10.4 and 12.7 $\%$, respectively) as compared to chemical fertilizer. Higher content of fructose sugar ( $11.6 \%$ ) was recorded in the combination between bio and chemical fertilizers with magnetized water as compared to the same fertilizers combination with non-magnetized water $(9.6 \%)$. Fibers content didn't seem to be affected by the water state in the treatment with a combination of both types of fertilizers (bio and chemo fertilizers; 12.6 vs. $12.8 \%$, respectively).

Table 6-Effects of water state and the fertilizer type on total chlorophyll $\mu \mathrm{mol} / \mathrm{m}^{2}$ andcontent of fructose sugar\% and fibers \% in fruit

\begin{tabular}{|c|c|c|c|}
\hline \multicolumn{4}{|c|}{ The leaves content from total chlorophyll $\mu \mathbf{m o l} / \mathbf{m}^{2}$} \\
\hline \multirow{2}{*}{ B } & \multicolumn{3}{|c|}{ A } \\
\cline { 2 - 4 } & Magnetized water & Non magnetized water & Rate \\
\hline Chemical fertilizer & 54.7 & 77.6 & 66.1 \\
\hline
\end{tabular}




\begin{tabular}{|c|c|c|c|}
\hline Bio and Chemical fertilizers & 60.8 & 90.0 & 75.4 \\
\hline Rate & 57.7 & 83.8 & \\
\hline CD 0.05 & \multicolumn{2}{|c|}{$\mathrm{A}=2.0, \mathrm{~B}=2.0, \mathrm{~A} \times \mathrm{B}=2.9$} \\
\hline
\end{tabular}

\begin{tabular}{|c|c|c|c|}
\hline \multicolumn{4}{|c|}{ Content of fructose sugar in fruits $\%$} \\
\hline & Magnetized water & Non magnetized water & Rate \\
\hline Chemical fertilizer & 6.8 & 6.7 & 6.7 \\
\hline Bio and Chemical fertilizers & 11.2 & 9.6 & 10.4 \\
\hline Rate & 9.0 & 8.1 & \\
\hline $\mathrm{CD} 0.05$ & \multicolumn{3}{|c|}{$\mathrm{A}=1.1, \mathrm{~B}=1.1, \mathrm{~A} \times \mathrm{B}=1.6$} \\
\hline \multicolumn{4}{|c|}{ Content of fibers in fruits $\%$} \\
\hline & Magnetized water & Non magnetized water & Rate \\
\hline Chemical fertilizer & 11.5 & 10.3 & 10.9 \\
\hline Bio and Chemical fertilizers & 12.6 & 12.8 & 12.7 \\
\hline Rate & 12.0 & 11.6 & \\
\hline CD 0.05 & \multicolumn{3}{|c|}{$\mathrm{A}=0.7, \mathrm{~B}=0.7, \mathrm{~A} \times \mathrm{B}=1.0$} \\
\hline
\end{tabular}

\section{Discussion}

The findings of present study indicate that the effect of magnetized water, bio and chemical fertilizers, and the combination between them were significant on all measured traits. These results are in agreement with those of Yadollahpour and colleagues [28] who reported that using magnetized water for irrigation led to increase the squash weight. The quantity and quality of bean plants and also fresh weight and shoot length of maize were improved by applying magnetized water [29]. The irrigation with magnetized water led to significant increments in the photosynthetic activity of carotenoids and chlorophylls in bean plants as compared with normal water [30]. High rates of traits such as yield/fed., chlorophylls ,TSS ,dry matter \%, total sugars, carbohydrates and crude protein \% and the lowest values of nitrate and nitrite were obtained in lettuce plants irrigated with magnetized water [31]. Irrigation with magnetized water plus the recommended dose of NPK (50\%) resulted in the maximum values of yield, carbohydrates, TSS and chlorophylls in strawberry plants [32]. Another study showed that magnetized water affected the vegetative growth of tomato by decreasing the time to maturity, promoting the rate of growth, and increasing yield [33]. The irrigation with magnetic water was superior to non-magnetic water in enhancement of onion's growth traits. This evidence collectively suggests that using magnetic water could be a promising technique for agricultural improvements [34]. It was demonstrated that Azospirillum and Azotobacter bacteria produce adequate amounts of cytokinins and Auxins (IAA) which accelerates plant growth by increasing the uptake of nutrients from the soil and increasing length of branches and roots [35,36]. A combination of Azotobacter chroococcum with Pseudomonas fluorescens was reported to improve broccoli 
growth[37]. Sarhan reported a positive effect of Azotobacter on growth and yield of potato plants [38]. It was revealed that seed inoculation with Azotobacter led to increments of fresh and dry weight of shoots, vine length and leaves number [39]. A study on summer squash plants showed that Azotobacter had significant effects on vegetative growth and improved the quantitative and qualitative traits of fruit yield of summer squash plants. The effects were more pronounced on the number of leaves, plant height, number of branches, fresh and dry weight of plants, fruit length, fruit diameter, total chlorophyll, and percentage of TSS [40]. Elwan and colleagues observed that the highest rate of fruit weight (g/fruit) and fruit yield (ton/fed.) were in squash plants inoculated with the double mixtures of Azospirillum brasilense and Sarratiam arcescens. Also, the double inoculation of Bacillus subtilis with Azospirillum brasilense significantly increased the fruit yield as compared with single inoculation [41]. Meena et al. reported that the combination between Azospirillum and fertilizers caused highly significant changes in traits of tomato plants such as the number of fruits per plant, fruit weight, plant yield per plant, yield (ton/ha) and TSS [42]. Application of biofertilizers (Azotobacter and Azospirillum) with a minimized recommended dose of nitrogen fertilizers is capable of improving fertility of soil and achieving higher productivity [26]. Interestingly, Azotobacter and Azospirillum could provide an opportunity to minimize the need for chemical nitrogen fertilizer by 50\% [43]. Moreover, the combination between a half dose of both the bacteria Azotobacter and Azospirillum caused a significant effect on growth and yield of Brassica juncea[44].It was also found that the Azotobacter chrocooccum, Azosprillium brasilense and Azosprillium lipoferum led to increase the yield of Canola (Brassica napus) by $21.17 \%$ more than chemical fertilizers [45].

\section{Conclusion}

According to the findings of this study, it can be concluded that the use of magnetized water was better than non-magnetized water in enhancing the growth traits of Butternut squash. Also, biofertilizers can be proper alternatives to reduce the use of chemical fertilizers, as the application of Azotobacter chrocooccum and Azosprillium brasilense with half dose of nitrogen fertilizer was superior on chemical fertilizer alone with full dose. Overall, the results showed that bio fertilizer application with the magnetized water was effective in improving performance of squash traits. However, further studies are needed to confirm these results with field research under different agroclimatic circumstances.

\section{Acknowledgments}

The authors would like to acknowledge the of College of Agriculture, University of Diyala and Directorate of Diyala Agriculture for their support to complete this study.

\section{References}

1. Jun, H., Lee, C. H., Song, G. S. and Kim, Y. S. 2006. Characterization of the pectic polysaccharides from pumpkin peel. LWT - Food Science and Technology, 39(5): 554-561. https://doi.org/10.1016/j.1wt.2005.03.004.

2. Daniel, A.L. 1995.Tropical pumpkin cultigen postharvest quality evaluation and maturity studies. M.Sc. Thesis. Univ. of Florida, Gainesville FL.

3. Azevedo- Meleiro, C. H., Rodriguez-Amaya, D. B. 2007. Qualitative and quantitative differences in carotenoid composition among Cucurbita moschata, Cucurbita maxima, and Cucurbita pepo. Journal of Agricultural and Food chemistry, 55(10): 4027-4033. https://doi.org/10. 1021/ jf06 341 3dPMid:17444652.

4. Kurz, C., Carle, R., Schieber, A. 2008. HPLC-DAD-MS characterization of carotenoids from apricots and pumpkins for the evaluation of fruit product authenticity. Food Chemistry, 110(2): 522-530. https://doi.org/10.1016/j.foodchem.2008.02.022 PMid:26049248.

5. Sharma, S. and Rao, T. V. R. 2013. Nutritional quality characteristics of pumpkin fruit as revealed by its biochemical analysis. International Food Research Journal, 20(5): 2309-2316.

6. Zhou, C. L, Liu, W., Zhao, J., Yuan, C., Song, Y., Chen, D., Ni, Y. Y., Li, Q. H. 2014. The effect of high hydrostatic pressure on the microbiological quality and physical-chemical characteristics of pumpkin (Cucurbita maxima Duch.) during refrigerated storage. Innovative Food Science and Emerging Technologie, 21: 24-34. https://doi.org/10.1016/j.ifset.2013.11.002.

7. Nawirska-Olszańska, A., Biesiada, A., Sokol-Letowska, A. and Kucharska, A. Z. 2014. Characteristics of organic acids in the fruit of different pumpkin species. Food Chemistry, 148 : 415-419. https://doi.org/10.1016/j.foodchem.2013.10.080 PMid:24262577. 
8. Babu, C. 2010. Use of magnetized water and polymer in agriculture. Tropical Res., 8: 806-810.

9. Grewal, H.S. and Maheshwari. B.L. 2011. Magnetized treatment of irrigation water and Snow pea and Chickpea seeds enhances early growth and nutrient contents of seedlings. BioElectromagnetics, 32: 58-65.

10. Sadeghipour, O. and P. Aghaei. 2013. Improving the growth of cowpea (VignaunguiculataL. Walp.) by magnetized water. J. Bio. and Env. Sci., 3(1): 37-43.

11. Hozayn, M.; A. Abd El-Monem; R. Abdelraouf and M. Abdalla.2013. Do Magnetized water affect water use efficiency, quality, and yield of sugar beet (Beta vulgaris L.),J. Agron., 12(1):1-10.

12. Hozayn, M. and AbulQados, A.M.S. 2011. Irrigationwith magnetized water, a novel tool for improving crop production in Egypt. $15^{\text {th }}$ International Water Technology Conf., IWTC-15.

13. Chen J. 2006. The combined use of chemical and organic fertilizer and or biofertilizer for crop growth and soil fertility. International Workshop on Sustained Management of the SoilRhizosphere System for Efficient Crop Production and Fertilizer Use. October, Thailand, pp. 1620.

14. Shehata MM. and El-khawas, SA. 2003. Effect of biofertilizers on growth parameters, yield characters, nitrogenous components, nucleic acids content, minerals, oil content, protein profiles and DNA banding pattern of sunflower (Helianthus annusL. cv. Vedock) yield. Pak. J. Biol. Sci., 6(14): 1257-1268.

15. Salim , H.A. , I. S. Salman, I.S. and Jasim, B.N. 2016.Ipm approach for the management of wilt disease caused by Fusarium oxysporum $f$. $s p$. lycopersicion tomato (Lycopersiconesculentum),Journal of Experimental Biology and Agricultural Sciences, 4: 742747.

16. Rokhzadi A, Asgharzadeh A, Darvish F, Nour-mohammadi G, Majidi E. 2008 . Influence of plant growth-promoting rhizobacteria on dry matter accumulation and yield of chickpea (Cicer arietinum L.) under field condition. Am-Euras. J. Agric. Environ. Sci., 3(2): 253-257.

17. Saikia SP, Jain V. 2007. Biological nitrogen fixation with non- legumes: an achievable able target or a dogma. Curr. Sci., 92(3): 317-322.

18. Tambekar DH, Gulhane SR, Somkuwar DO, Ingle KB, Kanchalwar SP. 2009. Potential Rhizobium and phosphate solubilizers as a biofertilizers from saline belt of Akola and Buldhana district (India). Res. J. Agric. Biol. Sci., 5(4): 578-582.

19. Anjum MA, Sajjad MR, Akhtar N, Qureshi MA, Igbal A, Jami RA, Hasan MU. 2007. Response of cotton to plant growth promoting rhizobacteria (PGPR) inoculation under different levels of nitrogen. J. Agric. Res., 45(2): 135-143.

20. Yasari E, Esmaeili AAM, Pirdashti H, Mozafari S. 2008. Azotobacter and azospirilum inoculants as biofertilizers in canola (Brassica napusL.) cultivation. Asian J. Plant Sci., 7(5): 490-494.

21. Azzan NA, Hassan EA, Hamad EH. 2009. The chemical constituent and vegetative and yielding characteristics of fennel plants treated with organic and bio-fertilizer instead of mineral fertilizer. Aust. J. Basic Appl. Sci., 3(2): 579-587.

22. Wani, S.P.1990. Inoculation with associative nitrogen fixing bacteria in cereal grain production improvement. Indian J. Microbiol., 30: 363-393.

23. Akbari, G.A., S.M. Arab, H.A. Alikhani, I. Allahdadi, M.H. Arzanesh. 2007. Isolation and selection of indigenous Azospirillum spp. and the IAA of superior strains effects on wheat roots. World J. Agric. Sci., 3(4): 523-529.

24. Kader, M.A., M.H. Mian and M.S. Hoque. 2002. Effect or Azotobacterinoculant on the yield and nitrogen uptake by wheat. J. boil. Sci., 4: 259-261.

25. Mahato P., Anoop Badoni and. Chauhan J. S. 2009. Effect of AzotobacterandNitrogen on Seed Germination and Early Seedling Growth in Tomato. Researcher, 1(4): 62-66.

26. Reddy .S, A. K. Singh, H. Masih, J. C. Benjamin, S. K. Ojha, P. W. Ramteke and A. Singla. 2018. Effect of Azotobactersp and Azospirillumsp on vegetative growth of Tomato

(Lycopersiconesculentum), Journal of Pharmacognosy and Phytochemistry,7(4): 2130-2137.

27. Fisher RA, Yates. 1968. Statistical method for research workers. Oliver and boyd ltd. Edinburgh and London, 10. 
28. Yadollahpour Ali, RashidiSamaneh and Fatemeh Kavakebian.2014.Applications of Magnetic Water Technology in Farming and Agriculture Development: A Review of Recent Advances, Current World Environment,vol. 9(3): 695-703.

29. Aladjadjiyan, A. 2002.Study of the influence of magnetic field on some biological characteristics of Zeamais. Journal of Central European Agriculture, 3(2).

30. Elsayed, H. 2014. Impact of magnetized waterirrigation for improving the growth, chemical composition and yield production of broad bean (ViciafabaL.) plant. American J. Exp. Agric., 4(4): 476-496.

31. Abdel Nabi, H. M. E.; K. K. Dawa; E. E. El-Gamily and Y.F.E. Imryed.2017. Effect of magnetized water, foliar application with nanomaterial and nitrogen levels on productivity and quality of head lettuce. Int.J. Adv. Res. Biol. Sci., 4(5): 171-181.

32. Abd El-Latif, A.A.; A.A. Abdelshafy and T.A. Eid. 2015. Minimizing strawberry mineral fertilization and enhancing water use efficiency by using magnetized irrigation water. J. Plant Production, Mansoura Univ., 6 (9): 1581 - 1593.

33. Yusuf, K.O. and A.O. Ogunlela. 2015. Impact of magnetized treatment of irrigation water on the growth and yield of tomato,Sci. Biol., 7(3): 345-348.

34. Ali ,A. F., Salim, H. A., Alsaady, M. H. M.2017. Impact of Magnetic Water Irrigation for Improve Growth Parameters of Two Onion Cultivars Allium cepa L.,Journal of Natural Sciences Research, 7(10): 75-77.

35. Jagnow, G.; G. Hoflich and K.H. Haffmann. 1991. Inoculation of non-symbiotic rhizosphere bacteria: Possibilities of increasing and stabilizing yields. Angew. Botanik. 65: 97-126 (C.A. Hort. Abst. 44 (2): 433, 1993).

36. Noel, T. C., C. Sheng, C.K. Yost, R.P. Pharis and M.E. Hynes. 1996. Rhizobium Leguminosarumas a plant growth -promoting rhizobacterium: direct growth promotion of canolaand lettuce. Can. J. Microbial, 42(3): 270 - 283.

37. Salim ,H.A, Aziz, A.K., Mahdi, M.H., Ali, M.A., Salman, M.H., Hussein, M.M., Mohammed, L.K., Ahmed, M.S., Khalil, A.Y. and Hadi, T.A. 2018. Effect of Bio-Fertilizers Azotobacterchroococcumand Pseudomonas fluorescenson Growth of Broccoli (Brassica oleraceaL. var. Italica) ,Journal of Advances in Biology, V: 11 Issue: 01,P 2236- 2240.

38. Sarhan, T. Z. 2008. Effect of biological fertilizers, animal residues, and urea on growth and yield of potato plant c.v. Desiree (Solanum tuberosomL.). Ph.D Dissert., Hort. Sci. and Landscape Design (Vegetable). Univ. of Mosul, College of Agric. and Forestry. Iraq.

39. Shehata, S.M., Saleh, S.A. and Junge, H. 2006. Response of sexual excretion and productivity of squash plants to some bio fertilizer treatments. FZB Biotechnik GmbH, GlienickerWeg 185, D 12489 Berlin,Gemany.

40. Sarhan, T Z., Mohammed, G.H. and Teli, J.A. 2011. Effect of bio and organic fertilizers on growth, yield and fruit quality of summer squash. Sarhad J. Agric. 27(3).

41. Elwan, M.W.M. and S.A.M. Abd el-azeem.2015.Effects of plant growth promoting rhizobacteria on Summer squash growth yield, nutrients uptake andAvailability under nitrogen and phosphorusFertilization levels , Arab Univ.J. Agric. Sci,.Ain Shams Univ, Cairo, 23(2): 497 - 513.

42. Meena ML, VS Gehlot, DC Meena, S Kishor, S Kishor, S Kumar and JK Meena. 2017. Impact of biofertilizers on growth, yield and quality of tomato (Lycopersiconesculentum Mill.) cv. PusaSheetal, Journal of Pharmacognosy and Phytochemistry; 6(4): 1579-1583.

43. Das, P. K., Ghosh, A., Choudhury, P. C., Katiyar, R. S. and Sengupta, K. 1990. Response of irrigated mulberry to Azotobacter and Azospirillumbiofertilizersundergraded levels of nitrogen. In Biofertilizer Technology Transfer (Ed. L. V.Gangawane), pp. 71 \pm 77 . New Delhi: Associated Publishing Co.

44. Irfan, K., Anwar, M. and Aquil, A. 2010. Effect of nitrogen fixingbacteria on plant growth and yield of Brassica juncea, Journal of Phytology, 2(9): 25-27.

45. Esmaeil,Y. and Patwardhan, A.M. 2007. Effects of (Azotobacterand Azosprillium) Inoculants and Chemical Fertilizers on Growth and Productivity of Canola (Brassica napus L.), Asian Journal of Plant Sciences, 6(1): 77-82. 